\title{
Pronunciation Goals of Japanese English Teachers in the EFL Classroom: Ambivalence Toward Native-like and Intelligible Pronunciation
}

\section{Yoko Uchida}

Tokyo University of Marine Science and Technology

\section{Junko Sugimoto}

\section{University of the Sacred Heart, Tokyo}

While there is a general concurrence among researchers that mastery of "intelligible pronunciation" should be the goal of English learners, the notion does not seem to be widely shared among non-native EFL teachers, who often hold the strong belief that teachers should sound like native speakers. To investigate the underlying reasons for this, we conducted an essay survey with 16 Japanese preservice teachers after having them read articles relevant to intelligible English and English as a lingua franca. The preservice teachers displayed ambivalence between native English pronunciation and Japanese-accented English. Some also had misunderstandings concerning "intelligible pronunciation." Limited communication experience in monolingual classrooms may have prevented them from imagining what type of pronunciation is necessary. We propose that intelligible non-native English samples be presented to preservice teachers in training courses to help them establish their concept of "ideal" pronunciation, which can serve as a model for their future students.

研究者の間では、英語学習者は「明瞭度の高い発音」の習得を到達 目標とするべきであるという考え方が一般的である。しかし、その考え 方は非母語話者の英語教員の間では広く共有されておらず、教員は母語 話者のような発音でなければならないと強く信じていることが多い。そ の背景にある理由について調査するために、16名の英語教員志望者に 対して「明瞭度の高い英語」と「国際共通語としての英語」に関する論 文記事を読んでもらつた後に、エッセイによる調査を行なつた。教員志 望者達は、英語母語話者の発音と日本語の痕跡が残つた発音に対して 葛藤する気持ちを示した。また、「明瞭度の高い発音」という概念につい て誤解している者もいた。教員と生徒が同じ母語を共有する教室内で英 語による意思疎通を行なうという限定的な経験しかないため、どのよう な種類の発音が必要であるのか想像できなかつたのかもしれない。教 員志望者自身が、将来生徒達のモデルとなれるよう、自身にとつての「理 想の」発音を身につけることが必要である。そのために、非母語話者の 発音であっても明瞭度の高い英語の実例を聞く機会を増やすなど、教員 養成の過程における工夫を提案したい。
W ith the recognition of the importance of the communicative aspects of English, more attention should be given to pronunciation instruction in Japan. Although selecting a pronunciation model and a goal for teachers is an important task, tackling it may not be straightforward.

While there are several possible pronunciation models, in Japan, North American English has mainly served as the norm in school education, including textbooks (Sugimoto \& Uchida, 2018a). Additionally, a survey in 2015 asking 100 public junior high school teachers indicated that $56 \%$ of the teachers preferred either standard British or American English, and 37\% standard American English (Uchida \& Sugimoto, 2019). While we acknowledge that within the field of accent studies there is debate about the term (Van Riper, 1986), as an "already existing, natural and ready-to-use native accents" (Szpyra-Kozłowska, 2015, p. 24), General American (GA) appears to be the most realistic accent to adopt as a production model in Japan. This is especially because teaching materials and resources based on GA are readily available. Nevertheless, considering English's place as a world language (Bolton, 2006), it is necessary to present varieties of English as receptive models.

As for the pronunciation goal, "intelligible pronunciation" is often considered sufficient (Abercrombie, 1949; Celce-Murcia, Brinton, \& Goodwin, 2010; Levis, 2005), mainly because the attainment of native-like pronunciation is not a realistic goal for the majority of non-native English (NNE) speakers (Derwing \& Munro, 2015). While often considered problematic, the dichotomy of native English (NE) versus NNE speakers is addressed in this article because the majority of Japanese English teachers tend to label themselves as NNE speakers.

Researchers use the term intelligible pronunciation in different ways. For example, Celce-Murcia, et al. (2010) describe it as "a modest and realistic 
goal [for learners] to surpass the threshold level so that their pronunciation will not detract from their ability to communicate" (p. 9). Jenkins (2000) claims that many learners' main goal is to communicate intelligibly with other NNE speakers and to not necessarily sound precisely like a NE speaker. She proposed Lingua Franca Core (LFC), a list of crucial pronunciation features to be produced accurately for intelligible communication. In our specific context, we define the concept intelligible pronunciation as pronunciation that can be understood by listeners without effort and can serve as a model for students, even with a slight Japanese accent.

While setting intelligible pronunciation as a goal is a commonly shared notion among researchers, it does not seem to be sufficiently acknowledged more broadly. Many studies have shown that both teachers and learners tend to set native-like pronunciation as their goal (Jenkins, 2007; Scales, Wennerstrom, Richard, \& Wu, 2006; Timmis, 2002). In the survey mentioned, the majority of teachers believed that NNE teachers should strive to acquire native-speaker accents, expressed intolerance of pronunciation with traces of a Japanese accent, and only half believed that pronunciation that does not inhibit communication is sufficient for teachers (Uchida \& Sugimoto, 2019). We asked the same questions to 16 university students who were taking the first author's phonetics course and found the same trend.

These Japanese in-service and preservice teachers' responses prompted us to further investigate the underlying reasons for their preference for native-speaker English. Thus, we address the following research question: Why do Japanese preservice teachers prefer native-speaker pronunciation when the more lenient goal of acquiring intelligible pronunciation is acceptable or even preferable? By answering this question, we hope to obtain some clues about directions to take in pronunciation instruction in preservice teacher training courses in universities.

\section{The Study}

The participants in this study were 16 Japanese undergraduate students (14 female, 2 male; Age: 19-27) who were enrolled in the phonetics course for preservice teachers. The distribution of their English proficiency in CEFR, measured by the Cambridge English Placement Test, was: C1 (1), B2 (7), B1 (7), and unknown (1).

After they completed one term of American English pronunciation training, the participants were introduced to concepts relevant to intelligible pronunciation and $\mathrm{LFC}$ by reading two texts that presented different perspectives regarding intelligible pronunciation. One was an excerpt from Celce-Murcia, et al. (2010, pp. 8-9) and the other an article by Shimizu (2011) that attempts to narrow the English sounds crucial to Japanese learners of English based on Jenkins' (2000) LFC. Following a group discussion of the two readings, focusing on what "a threshold level [of intelligible pronunciation]" (Celce-Murcia, et al., 2010, p. 8) and "intelligible pronunciation" (Jenkins, 2000, p. 123) in LFC are, the preservice teacher participants were asked to answer an open-ended essay question: What kind of pronunciation should English teachers aim for?

An iterative process was applied to categorize the obtained data (Kekeya, 2016; Srivastava \& Hopwood, 2009). The responses were grouped into units of meaning and examined for common issues. Five categories were identified (see Table 1), from which units relevant to the teacher's role as a pronunciation model and the teacher's own pronunciation goals were retrieved, with commonalities and differences among the units elucidated. To ensure reliability, two researchers performed a parallel analysis of the data and any discrepancies were discussed until agreement was reached. The original Japanese responses have been translated into English by the authors.

\section{Results}

A total of 202 units based on the participants' responses were generated, with the average number of units obtained per participant 12.63 (range: 9-17). The five categories obtained through the first round of analysis were: teacher's role (26 units), teacher's pronunciation (70), students' pronunciation (10), opportunities for English use (8), and others (88). Units in each category were further classified into themes (see Table 1). The units in "others" mostly included irrelevant comments such as citations of reading materials and personal experiences/introspections without a clear indication of their attitudes toward pronunciation and were not included in further analysis. Results concerning pronunciation models (15) and teacher's goals (50) will mainly be reported on in the following sections, as many of the comments reflect their opinions regarding teacher's pronunciation goals. See the Appendix for representative comments from the participants. 
Table 1. Participants' Responses Divided Into Categories and Themes

\begin{tabular}{|c|c|}
\hline Category & Theme \\
\hline 1. teacher's role (26) & $\begin{array}{l}\text { pronunciation models (15), } \\
\text { contents of instruction } \\
\text { (8), purpose of instruction } \\
\text { (2), other (1) }\end{array}$ \\
\hline $\begin{array}{l}\text { 2. teacher's } \\
\text { pronunciation }(70)\end{array}$ & $\begin{array}{l}\text { teacher's goals }(50), \\
\text { items to be acquired (8), } \\
\text { practice of pronunciation } \\
\text { (6), knowledge of } \\
\text { pronunciation (6) }\end{array}$ \\
\hline $\begin{array}{l}\text { 3. students' } \\
\text { pronunciation (10) }\end{array}$ & $\begin{array}{l}\text { students' goals (5), } \\
\text { items to be acquired (3), } \\
\text { motivation (2) }\end{array}$ \\
\hline $\begin{array}{l}\text { 4. opportunities for } \\
\text { English use (8) }\end{array}$ & $\begin{array}{l}\text { few opportunities (5), } \\
\text { many opportunities ( } 3 \text { ) }\end{array}$ \\
\hline 5. others (88) & - \\
\hline
\end{tabular}

Total (202)

\section{Teachers as Pronunciation Model}

The preservice teachers seemed to agree that the teacher's pronunciation should be of a higher standard than that of the students to positively influence them through inspiring higher motivation and admiration of the teacher. While some considered native-like pronunciation to be an ideal pronunciation model because it is "better" and students "should get used to it," others said intelligible pronunciation, even with a Japanese accent, is ideal because it is "easier" and "familiar" to students, and so can lead to higher motivation. Two said native-like pronunciation should be avoided as a model because it can "confuse" students; conversely, one said that Japanese-accented pronunciation should be avoided because students will copy "bad habits."

\section{Teacher's Goals}

Three of the pre-service teacher participants claimed teachers should aim for native-like pronunciation. Overall, these three seemed to consider it superior to non-native varieties of pronunciation, since they believed it is advantageous in various ways. For example, it would enable them to communicate with both NE and NNE speakers smoothly. It would also help them instruct students in achieving the threshold level of intelligible pronunciation, and without native-like pronunciation, they felt they would not be able to demonstrate appropriate pronunciation and give students advice on how to improve.

Conversely, some participants insisted that teachers do not have to have native-like pronunciation. Many claimed NNE teachers could not remove their accent and that different targets should be set; for example, "a threshold level of pronunciation" (2 comments), "LFC pronunciation" (2 comments), and a level at which "listeners can understand what they say" (1 comment). One said they could communicate with other NNE speakers successfully without native-like pronunciation. Another indicated that native-like pronunciation is available from audio materials, assistant language teachers (ALT), or the Internet. There was a comment that native-like pronunciation should be avoided because students would be overwhelmed by the differences between Japanese and English sounds.

There were also several indecisive comments: Native-like pronunciation is ideal or preferable, but intelligible pronunciation is a more realistic goal; it is sufficient, or more accessible to students who are in the process of learning. One said that the majority of teachers need not have native-like pronunciation because it is only required as a model for higher-level students. Participants who expressed the opinion that native-like pronunciation is not necessary added that a certain standard should be maintained, such as fluency, minimum intelligible pronunciation for English as an international language, and the ability to produce understandable English. There was a comment that even though it is not a requirement, a teacher's demonstration of native-like pronunciation is valuable because students can realize that English has sounds that are very different from Japanese.

\section{Discussion}

In answering the research question, the voices of the preservice teachers in the present study conveyed the complexities and mixed feelings associated with what ideal pronunciation represents for teachers. Additionally, the preservice teachers seemed to have some misunderstandings concerning what intelligible English is.

\section{Ambivalent Feelings Toward Pronunciation}

The preservice teachers' comments highlight their views toward native versus non-native English speaker pronunciation. For native-like pronunciation, they used positive expressions such as "better," "intelligible," "correct," and "desirable" along with the negative expressions "unattainable" and "intimidating." In contrast, Japanese-accented English 
was associated with positive expressions such as "realistic," "attainable," and "intelligible (to students)," while negative impressions such as "not acceptable," "bad habits," and "difficult to understand" were also expressed. Most of the preservice teachers appear to believe that native-like pronunciation is an unattainable goal. However, while some accept pronunciation with a Japanese accent if it is intelligible, others apparently cannot abandon the idea that teachers should acquire native-like pronunciation and are determined to achieve this challenging goal. However, none of the respondents claimed with certainty that they supported either side as their pronunciation goal. Unlike the dichotomous question of whether the preservice teachers strive for native-like or Japanese-accented pronunciation, the current essay-type survey revealed the NNE speaking teachers' in-depth, complicated attitudes toward pronunciation goals even though there were only 16 participants.

\section{Misunderstandings Concerning Intelligibility}

The examination of the comments revealed a couple of preservice teachers' misunderstandings concerning intelligibility. One is the mistaken notion that NE pronunciation is more intelligible than NNE pronunciation. This is understandable because NE-speaking ALTs enunciate clearly in front of the class, and textbook audio materials are spoken slowly and clearly (Sugimoto \& Uchida, 2018a). Naturally, it is difficult for Japanese teachers and students to imagine that native varieties can be unintelligible. However, as is indicated by Moussu and Llurda (2008), NE speakers' pronunciation can be harder to understand than educated NNE speakers' pronunciation.

The other is a misunderstanding about how to achieve intelligible pronunciation. One preservice teacher indicated the need for teachers to adjust their pronunciation, suggesting that including some Japanese accents can contribute to better student English comprehension. Another implied the usefulness of Japanese-accented English for its intelligibility to avoid "unintelligible" and "intimidating" NE pronunciation. However, these preservice teachers need to recognize that "intelligible pronunciation" achieved this way can lead to "fake intelligibility." Such pronunciation is most likely unintelligible to speakers with different language backgrounds because the pronunciation is only accommodated to a Japanese L1 audience, which only works in "monolingual classes" (Walker, 2010, p. 92). Even though communication with speakers with language backgrounds different from their own was clearly indicated in the texts and was also assumed in the class discussion, the thought of who students need to communicate with appears to have slipped the minds of some of the preservice teachers in their essays. This could be partially attributed to their lack of experience interacting with English speakers with diverse backgrounds.

\section{Proposals for Mastery of "Intelligible Pronunciation"}

Although we should respect preservice teachers' ambitions to pursue native-like pronunciation, it is also necessary to draw their attention to the strengths of NNE teachers (Braine, 2010; Murphy, 2014a). For example, NNE teachers have an advantage over NE teachers in that they were learners themselves and are therefore knowledgeable of students' learning difficulties. Moreover, because many teachers in Japan share an L1 with their students, it is easy for them to predict the kinds of L1 transfer difficulties they are likely to encounter.

While many preservice teachers wish to have higher-level pronunciation than their students, to our knowledge, no studies have clearly defined the type of pronunciation teachers should acquire, suggesting that acceptable pronunciation for teachers has yet to be explored. An experimental study by Sugimoto and Uchida (2018) employed acceptability ratings and successfully identified lower-level pronunciation samples to be unacceptable for teachers, but there was variability in judging acceptable pronunciation samples, so further research is required to define acceptable pronunciation for English teachers.

As for intelligibility, unfortunately, studies have reported negative attitudes toward the Japanese accent outside Japan (e.g., Jenkins, 2007), which suggests the need for Japanese English speakers to be trained in accommodating their speech in interactions with both NE and NNE speakers. Even communication breakdowns and the experience of resolving them can be beneficial. Only then will they be able to truly understand what intelligible pronunciation is. Further investigation is necessary because previous studies have not provided convincing data about which aspects of the Japanese accent affect intelligibility.

The results of this study suggest that the Japanese preservice teachers had insufficient exposure to different varieties and types of English and lacked confidence in their pronunciation as NNE speakers. This is likely the case with preservice teachers in general. Their misconceptions may be rectified by listening to a wider variety of NE accents and intelligible NNE pronunciation, which 
can serve as ideal models (Murphy, 2014b). It is hoped this will help teachers recognize that they should enhance their students' speaking skills, not as native-sounding speakers but as speakers who can communicate confidently and efficiently in English using appropriate pronunciation and communication strategies.

\section{Conclusion}

The present study indicated that behind Japanese preservice teachers' preference for NE pronunciation lies ambivalence toward native-like pronunciation and Japanese-accented pronunciation, along with misunderstandings concerning what "intelligible English" is. For preservice teachers to truly understand that their goal should be intelligible pronunciation, some measures need to be introduced in their teacher training. For example, providing opportunities to interact with speakers of English from a variety of language backgrounds is essential. Furthermore, the strengths of NNE teachers should be emphasized. Presenting samples of intelligible NNE pronunciation will help encourage them to set more attainable goals. This way, it will be possible for Japanese preservice teachers to truly comprehend the notion and importance of acquiring intelligible English for speaking to both NE and NNE speakers.

\section{Acknowledgments}

This study is an extension of an oral presentation (Uchida \& Sugimoto, 2017), to which additional analysis from different perspectives was applied. The authors are grateful to the audience of ELF10 for their constructive feedback. We also thank the anonymous reviewers for their valuable and helpful comments.

\section{References}

Abercrombie, D. (1949). Teaching pronunciation. ELT Journal, 3(5), 113-122. https://doi.org/10.1093/elt/ III.5.113

Bolton, K. (2006). Varieties of world Englishes. In B. B. Kachru, Y. Kachru, \& C. L. Nelson (Eds.) The handbook of world Englishes (pp. 289-312). Oxford, UK: Blackwell Publishing Ltd. https://doi. org/10.1002/9780470757598.ch17

Braine, G. (2010). Nonnative speaker English teachers: Research, pedagogy, and professional growth. New York: Routledge. https://doi.org/10.4324/9780203856710

Celce-Murcia, M., Brinton, D. M., \& Goodwin, J. M. (2010). Teaching pronunciation: A course book and reference guide. New York: Cambridge University Press.
Derwing, T. M., \& Munro, M. J. (2015). Pronunciation fundamentals. Amsterdam: John Benjamins Publishing Company. https://doi.org/10.1075/1llt.42

Jenkins, J. (2000). The phonology of English as an international language. Oxford: Oxford University Press.

Jenkins, J. (2007). English as a lingua franca: Attitude and identity. Oxford: Oxford University Press.

Kekeya, J. (2016). Analysing qualitative data using an iterative process. Contemporary PNG Studies: DWU Research Journal, 24, 86-94.

Levis, J. M. (2005). Changing contexts and shifting paradigms in pronunciation teaching. TESOL Quarterly, 39, 369-377. https://doi.org/10.2307/3588485

Moussu, L., \& Llurda, E. (2008). Non-native Englishspeaking English language teachers: History and research. Language Teaching, 41(3), 315-348. https://doi. org/10.1017/S0261444808005028

Murphy, J.M. (2014a). Teacher training programs provide adequate preparation in how to teach pronunciation. In L. Grant (Ed.), Pronunciation Myths (pp. 188-224). Ann Arbor: University of Michigan Press.

Murphy, J. M. (2014b). Intelligible, comprehensible, nonnative models in ESL/EFL pronunciation teaching. System, 42, 258-269. https://doi.org/10.1016/j. system.2013.12.007

Scales, J., Wennerstrom, A., Richard, D., \& Wu, S. H. (2006). Language learners' perceptions of accent. TESOL Quarterly, 40, 715-737. https://doi. org/10.2307/40264305

Shimizu, A. (2011). English as a lingua franca and the teaching of pronunciation. Journal of the Phonetic Society of Japan, 15(1), 44-62.

Srivastava, P., \& Hopwood, N. (2009). A practical iterative framework for qualitative data analysis. International Journal of Qualitative Methods, 8(1), 76-84. https://doi. org/10.1177/160940690900800107

Sugimoto, J., \& Uchida, Y. (2018a). How pronunciation is taught in English textbooks published in Japan. Seishin Studies, 130, 3-35.

Sugimoto, J., \& Uchida, Y. (2018b). Accentedness and acceptability ratings of Japanese English teachers' pronunciation. In J. Levis (Ed.), Proceedings of the 9 th Pronunciation in Second Language Learning and Teaching conference (pp. 30-40). Ames, IA: lowa State University.

Szpyra-Kozłowska, J. (2015). Pronunciation in EFL instruction: A research-based approach. Bristol: Multilingual Matters. https://doi.org/10.21832/9781783092628

Timmis, I. (2002). Native-speaker norms and international English: A classroom view. ELT Journal, 56(3), 240-249. https://doi.org/10.1093/elt/56.3.240

Uchida, Y., \& Sugimoto, J. (2017, June). Towards the implementation of ELF-oriented pronunciation teaching in Japan. Oral presentation at the meeting of ELF 10 and Changing English: 10th Anniversary Conference of English as a Lingua Franca, Helsinki, Finland. 
Uchida, Y., \& Sugimoto, J. (2019). Non-native English teachers' confidence in their own pronunciation and attitudes towards teaching: A questionnaire survey in Japan. International Journal of Applied Linguistics, 1-16. https://doi.org/10.1111/ijal.12253

Van Riper, W. R. (1986). General American: An ambiguity. In H. B. Allen \& M. D. Linn (Eds.) Dialect and Language Variation (pp. 123-135). New York: Harcourt Brace Jovanovich. https://doi.org/10.1016/B978-0-12-0511303.50013-6

Walker, R. (2010). Teaching the pronunciation of English as a lingua franca. Oxford: Oxford University Press.

Yoko Uchida is a Professor at Tokyo University of Marine Science and Technology. Her research interests include teaching pronunciation and Maritime English. One of her current research topics is pursuing the intelligibility levels expected of different groups of native Japanese speakers who use English in different contexts and for different purposes.

Junko Sugimoto is an Associate Professor at the University of the Sacred Heart, Tokyo. Her research interests include acquisition of rhythm and intonation by EFL learners, teaching pronunciation, and intelligibility. She is currently focusing on how to effectively teach selected segmentals and suprasegmentals to improve the intelligibility of Japanese learners' English.

\section{Appendix}

Representative comments obtained from the 16 participants

\section{A. Teachers as Pronunciation Model}

1. What is an "ideal pronunciation model" for students?
a. Pronunciation with a higher standard than that of students
b. Good pronunciation that prompts higher student motivation
c. Pronunciation that the students will admire and aspire to
d. Pronunciation that can influence students' pronunciation

2. Those who preferred native-like pronunciation think:
a. By using it, students will get used to na- tive-like pronunciation.
b. It serves as a better model.

3. Those who think intelligible pronunciation takes priority over native-like English think:
a. It is more practical and easier for students to learn.
b. Even with a Japanese accent, it is clearer and familiar to students and leads to higher motivation.

4. A pronunciation model that should be avoided is:
a. Native-like English because it can confuse beginner-level students and make them reluctant to study English.
b. Japanese-accented English because students will copy bad habits.

5. An alternative way for NNE-speaking teachers to acquire native-like pronunciation is:

a. Native speaker pronunciation is available through audio materials, so NNE-speaking teachers do not need to sound like native speakers.

\section{B. Teacher's Goals}

1. Teachers should aim for native-like pronunciation:

a. Teachers should not stick to the threshold level but seek to approximate native-like pronunciation.

b. Teachers should attain pronunciation that approximates NE speakers' pronunciation so that they can have their students achieve a threshold level of pronunciation.

c. Teachers should attain pronunciation like that of an NE speaker, because it will make smooth communication possible between an NE speaker and an NNE speaker and between NNE speakers.

d. Despite how difficult it may be, all NNE speakers should achieve native-like pronunciation because it is unrealistic to tune in to different accents every time one encounters speakers of different mother tongues.

e. Teachers should aim for native-like pronunciation because to me learning a language is directly connected to understanding the native speakers' culture, which includes their pronunciation.

f. Teachers should try to approximate, in their pronunciation, Received Pronunciation (RP) or GA, although the speakers of these varieties are minorities compared to all the English speakers in the world, since teachers should be able to instruct students who wish to acquire native-like pronunciation as well as those who wish to acquire pronunciation that enables a minimal level of communication.

g. It is important for teachers to acquire pronunciation that is close to RP or GA to demonstrate it and provide appropriate 
advice. Unless the teachers' pronunciation is good enough, it will be difficult for them to be good pronunciation models for their students and give advice on improvement.

2. Native-like pronunciation is NOT necessary:

a. Teachers do not need to aim for native-like pronunciation because ALTs are available at many schools and we can experience NE speakers' English any time on the Internet.

b. It is unrealistic to attain a quality of pronunciation equivalent to NE speakers.

c. It is not necessary to be as accurate as native speakers in pronunciation.

d. A threshold level of pronunciation is sufficient for teachers because for us NNE speakers it suffices to be able to communicate with other NNE speakers.

e. NNE-speaking teachers do not need to have native-like pronunciation because, as my mentor told me during the practicum, pronunciation that is comprehensible to students should be given priority over better pronunciation. He also told me that students can listen to NE speakers' pronunciation through ALT and audio materials and that nurturing students' attitudes toward communicating with sincerity is more important.

f. Native-like pronunciation is not necessary because the students, many of whom are native Japanese speakers, are likely to be overwhelmed by the great differences between Japanese and English sounds.

g. Speaking like native speakers is not necessary, simply because I think it is impossible for NNE speakers to completely remove their accents.

h. It is not necessary to aim for native-like pronunciation because English is spoken all over the world. Teachers should strive for LFC pronunciation instead.

i. Achieving native-like pronunciation is not necessary because the most important thing for us is to be able to speak English in such a way that listeners can understand.

3. Native-like pronunciation is ideal/preferable, and we should make an effort to attain it, BUT:

a. It may suffice to set a goal for pronunciation that leaves a trace of the Japanese accent but is nevertheless intelligible as pronunciation to demonstrate to students since it is more realistic to achieve.

b. I think it is satisfactory for an English teacher if $s$ /he has achieved a level of pronunciation that does not hamper communication with both NE and NNE speakers.

c. Since the students are still at a learning stage, English with a Japanese accent may be more intelligible.

d. It is not essential. Since teachers themselves are NNE speakers, it is OK to show traces of the native language.

e. We need teachers who have native-like pronunciation only for higher-level students who may in the future obtain jobs that require good English pronunciation such as professors overseas and interpreters.

4. Native-like pronunciation is NOT necessary or required of NNE-speaking teachers, BUT ...:

a. Fluency is required to some extent.

b. They should rather aim for minimal intelligible pronunciation from the viewpoint of "English as an International Language."

c. Acquiring knowledge of the weak points and habits of $\mathrm{L} 2$ speakers and being able to provide instruction regarding pronunciation based on such knowledge is required. Teachers should also strive to remove their own bad habits.

d. Native-like English is preferable as pronunciation to present to students.

e. Moderately good pronunciation intelligible to NE speakers is essential for teachers to demonstrate to students that it is possible to make ourselves understood in English even with some degree of Japanese accent.

f. Providing students with opportunities to experience that "English is a totally different language from Japanese in terms of pronunciation" during class is valuable.

5. Others

a. Teaching English covers a wide range of topics, and pronunciation is only one of them. After reaching the so-called "threshold level," teachers should shift their focus to areas such as grammar and vocabulary instead of devoting all their energy to pronunciation.

b. Since most English teachers must have a certain level of grammar and vocabulary, I think NE speakers should be able to understand their English unless their pronunciation is disastrously bad. English teachers should attain pronunciation that NE speakers can easily understand, and I think that English learners in general should be able to reach that goal effortlessly. 